\title{
CEOs and Quiet Life Hypothesis - A Comparative Study on SBI and other Public Sector Banks in India
}

\author{
Pushkala Narasimhan ${ }^{1}$, K. A. Venkatesh ${ }^{2 *}$ and J. Mahamayi ${ }^{3}$ \\ ${ }^{1}$ Coordinator, P. G., Department of Commerce, NMKRV College for Women, Bangalore - 560041, \\ Karnataka, India \\ 2Professor, Myanmar Institute of Information Technology, Mandalay, Myanmar \\ ${ }^{3}$ V.V.V. College for Women, Virudhunagar - 626001, Tamil Nadu, India
}

\begin{abstract}
Quiet Life Hypothesis is a concept which ensures the players in an industry achieving and attaining the highest market share. But Quiet life is also possible with the very strong strategic and efficient leadership at CEO level of any organisation. Their tenure makes the organisation to emerge as industry's behemoth like SBI. The QLH is tested in the Banking sector especially State Bank of India. Nevertheless, to say Ms. Arundhati Bhattacharya took over as CEO of SBI in Oct, 2013 and with her extended tenure till Oct 2017, she made SBI as the most efficient bank among all public sector banks in handling demonetisation, GST and implementing the road map of merger of all associate banks of SBI and Bharatiya Mahila Bank. The legacy of Ms. Arundhati left SBI in an extremely strategically stronger position than before she became CEO. This paper reveals that the exit of hers made SBI reap the benefits of Quiet Life in comparisons with other public and private sector banks in India.
\end{abstract}

Keywords: Efficiency of Banks, Market Concentration and Lerner's Index

\section{Introduction}

In recent past the growth rate of banking industry in India is impressively high, due to mergers \& acquisitions and policy of the Union Government. State Bank of India and its associates fused as one entity and few more such mergers in the pipeline. Banking Industry is the backbone of any country's economy and these mergers will have impact on the economy. On the other hand, the market competition is in process of consolidating towards a high position. To retain the market power, the mergers forced to spend more. Because of the market power, many firms would not put effort towards the efficiency. This article explores the Quite Life Hypothesis (QLH) among the Public sector banks in India as two groups namely SBI \& associates and other Public sector banks, for the period 2013-18.
Quiet Life for the participants in the banking sector is ensured in achieving and attaining the highest market share. But Quiet life is also possible with the very strong strategic and efficient leadership at CEO level of any organisation. Their tenure makes the organisation to emerge as industry's behemoth like SBI. Nevertheless, to say Ms. Arundhati Bhattacharya took over as CEO of SBI in Oct, 2013 and with her extended tenure till Oct 2017, she made SBI as the most efficient bank among all public sector banks in handling demonetisation, GST and implementing the road map of merger of all associate banks of SBI and Bharatiya Mahila Bank. The legacy of Ms. Arundhati left SBI in an extremely strategically stronger position than before she became CEO. Whether the exit of hers made SBI reap the benefits of Quiet Life? 
This study explores the efficiency of these banks during and post exit performance of the public sector banks to conclude whether Quiet life Hypothesis has been proven with various tools applied in this study.

\subsection{Objectives of the study}

1. To understand the concept of Quiet Life Hypothesis and its application

2. To explore the achievements of the CEOs and their role in improving Banking performance

3. To study the performance of SBI during the tenure of the CEOs and after their exit.

This study is done as a two-step process: the first step is to obtain the bank level efficiency using the nonparametric approach i.e. Data Envelopment Analysis (DEA) and the second step is to obtain the market competition using Lerner's Index (LI) and finally the identify the relationship between the LI and DEA. This study supports the QLH but not in a greater way. That is the efficiency of banks is not affected, pre and post of the exit of Ms. Bhattacharya.

This article structured as follows: section 2 provides the review of literature, section 3 explains the data methodology deployed, section 4 offers the result analysis and the last section 5 deals with the conclusion of the study.

\section{Review of Literature}

Mihir N. Mehta (N.Mehta, 2010) in his doctoral thesis examined the quality of financial reporting under the protectionist Anti-Takeover laws in Delaware during period 1999-2000. Such protectionist laws gave a quiet life period to managers, who in turn decreased the number of effective managerial decisions related to value maximisation. The researcher found that the greater quality of financial reporting mitigates the adverse impact of Quiet-Life on managerial decisions.

The Quiet Life Hypothesis (Rolf Fare, 2015) was tested on Spanish banking industry considering various measures of efficiency like cost efficiency, technical efficiency and allocative efficiency. Since substantial changes happened in Spanish banking industry resulted in market concentration or market power, the QLH was tested among the two sets of Spanish banks such as commercial banks and savings banks by applying nonparametric tests. The study revealed that; the different components of efficiency resulted in contradictive outcomes with QLH.

(Odhiambo, 2019) Given the under-developed nations of Africa, the study focused on the Quiet Life Hypothesis and their policy implications of the Governments measure their efficiency or inefficiency. This study considered accessibility of funds and cost of such funds as dependent variables and among various independent variables mainly the market influence was measured with Lerner Index. With two stage least square model, they assessed the impact of Quiet Life Hypothesis on different set of banks like small banks, Domestic banks and Islamic banks in various African nations.

(Liem, 2019) This study evolved a new concept called 'Holdinglisation' in the place of QLH and found that the holding of all banks under the ownership of Indonesian Government impacted profitability vis-àvis inefficiency. The author feared that the outcomes of the study should be the caution to the Government in overcoming the failure or insolvency of such banks in turn, it would save the country from macro-economic crisis. The researcher used Bank efficiency Index, Bank soundness rating and their impact on Return on Average Assets. The conclusion of the study is that, QLH reborn is not relevant for Indonesian state-owned banks.

(Asongu, S.A., Odhiambo, N.M., 2019). In this study, proved that the QLH is consistent with the quest of financial intermediation inefficiency, in order to establish their hypothesis utlitized the Lerner Index and two stage least squares by considering 162 banks from 42 countries for a period of eleven years.

(Kotaru, 2018) This study questioning about the manager's behaviour and proved that mangers put off hard decisions without any monitoring and competition with Japanese firm data. 


\section{Data and Methodology}

The study is based on the secondary data available on RBI website, called Statistical Tables Related to Banking in India (STRBI) and other computations carried out the statistical software R.

In this article, the Data Envelopment Analysis (DEA) is applied to obtain the Efficiency of the individual Banks and Cobb Douglass cost function to obtain the marginal cost. Then to identify the market competition using Learner's Index (LI) and finally regression is used to establish the relationship between the LI and Cost Efficiency.

\subsection{Efficiency}

DEA was introduced by Charnes et al., (1978) which is a linear programming model and popularly known as CCR model. In DEA literature, every firm is called as Decision Making Unit (DMU) and the efficiency scores of each DMU is determined as the maximum of weighted outputs to weighted inputs. The underlying assumption in CCR model is that all DMU's are optimal at the operational level. Another important aspect is the elasticity of Scale. The CCR model operates with Constant Return to Scale. CCR model geometrically operates on the conical hull. This model was extended by Banker et al., (1984) by introducing the Variable Returns to Scale in lieu of CRS and this model is popularly known as BCC model. The major difference of the BCC model over the CCR model is that $\mathrm{BCC}$ model operates on the convex hull.

The fractional model is converted to linear programming problem and given by

$$
\begin{aligned}
& \operatorname{Max}_{u, v} z=u_{1} y_{1, j}+u_{2} y_{2, j}+\cdots,+u_{n} y_{n, j} \\
& \mathrm{v}_{1} \mathrm{x}_{1, \mathrm{j}}+\mathrm{v}_{2} \mathrm{x}_{2, \mathrm{j}}+\cdots+\mathrm{v}_{\mathrm{m}} \mathrm{x}_{\mathrm{m}, \mathrm{j}}=1 \\
& \mathrm{u}_{1} \mathrm{y}_{1, \mathrm{j}}+\mathrm{u}_{2} \mathrm{y}_{2, \mathrm{j}}+\cdots+\mathrm{u}_{n} \mathrm{y}_{\mathrm{n}, \mathrm{j}} \leq \mathrm{v}_{1} \mathrm{x}_{1, \mathrm{j}}+\mathrm{v}_{2} \mathrm{x}_{2, \mathrm{j}}+\cdots+\mathrm{v}_{\mathrm{m}} \mathrm{x}_{\mathrm{m}, \mathrm{j}} \\
& \mathrm{u}_{\mathrm{i}} \geq 0(1 \leq \mathrm{i} \leq \mathrm{n}) \& \mathrm{v}_{\mathrm{j}} \geq 0(1 \leq \mathrm{j} \leq \mathrm{m})
\end{aligned}
$$

The BCC model is given by

$\mathrm{z}^{*}=\operatorname{mini} \mathrm{z}$
Subject to

$$
\begin{gathered}
\sum_{\mathrm{j}=1}^{\mathrm{k}} \mathrm{x}_{\mathrm{ij}} \lambda_{\mathrm{j}} \leq \mathrm{zx}_{\mathrm{i} 0} \cdot 1 \leq \mathrm{i} \leq \mathrm{n} \\
\sum_{\mathrm{j}=1}^{\mathrm{k}} \mathrm{y}_{\mathrm{rj}} \lambda_{\mathrm{j}} \leq \mathrm{y}_{\mathrm{r} 0} . \quad 1 \leq \mathrm{r} \leq \mathrm{m} \\
\sum_{\mathrm{j}=1}^{\mathrm{k}} \lambda_{\mathrm{j}}=1 \\
\lambda_{\mathrm{j}} \geq 0, \forall \mathrm{j}
\end{gathered}
$$

The efficiency of every DMU always lies between 0 and 1. A DMU is fully efficient only its efficiency score is 1 . DMUs are ranked based on the efficiency scores. (Venkatesh K A \& Pushkala N, 2019)

In our study, the inputs are Cost of Physical Capital (CPC), Cost of Funds (COF) and Labour Cost (LC) and a single output Total Revenue. The number of DMU's are twenty-six public sector banks in India and the period of study is 2013 t0 2018. The Average efficiency score obtained by DEA is depicted in (Table 1).

\subsection{Market Competition}

In this study Lerner Index is used to obtain the market competition. In the literature, various methods were used to study the competition in the Banking Industry. Among the various methods, the popular and widely used methods are Herfindahl Hirschman Index (HHI), K-Bank Concentration and Panzar-Roose-H statistic. The reason for choosing Lerner's Index is that it is easy to compute for each bank for every year and it coincides with the determinants of the banks. The Lerner's index is given by

$$
\mathrm{L}_{\mathrm{it}}=\frac{\mathrm{P}_{\mathrm{it}}-\mathrm{MC}_{\mathrm{it}}}{\mathrm{P}_{\mathrm{it}}}
$$

Where, $i$ is the respective Price and Marginal Cost of ith Bank in the year $t$.

The index ranges from 0 to 1 . The numbers closer to 1 indicates that higher market power and the lesser competition. Based on the Lerner index value, the bank has right to fix the price above the marginal cost. Lerner's Index is a direct measure to obtain the market power and hence the competition. Using the CobbDouglass Cost Function is used to obtain the Marginal Cost of each bank year wise. 
The Marginal Cost is obtained by the trans log cost function given by the equation

$$
\begin{aligned}
\operatorname{Ln}(\mathrm{TC})=\alpha_{0} & +\alpha_{1} \ln (\mathrm{TA})+\alpha_{2} 0.5\left(\ln (\mathrm{TA})^{2}+\beta_{1} \mathrm{LC}+\beta_{2} \mathrm{CPC}+\beta_{2} \mathrm{COF}\right. \\
& +\beta_{12} \ln (\mathrm{CPC}) * \ln (\mathrm{COF})+\beta_{13} \ln (\mathrm{CPC}) * \ln (\mathrm{LC})+\beta_{21} \ln (\mathrm{COF}) \\
& * \ln (\mathrm{LC})+\gamma_{1} \ln (\mathrm{TA}) * \ln (\mathrm{CPC})+\gamma_{2} \ln (\mathrm{TA}) * \ln (\mathrm{COF})+\gamma_{3} \ln (\mathrm{TA}) \\
& * \ln (\mathrm{LC})+\varepsilon
\end{aligned}
$$

Where, TC is the total cost, TA-Total Assets, CPCCost of the Physical Capital, COF-Cost of the Fund and LC-Labour Cost. On computing the coefficients of the previous formula, the Marginal Cost is obtained using $\mathrm{MC}=\frac{\mathrm{TC}}{\mathrm{TA}}\left(\alpha_{0}+\alpha_{2} 0.5 \ln (\mathrm{TA})+\right.$ $\left.\gamma_{1} \ln (\mathrm{CPC})+\gamma_{2} \ln (\mathrm{COF})+\gamma_{3} \ln (\mathrm{LC})\right)$.

\section{Result and Analysis}

\subsection{Competition and Banking Efficiency}

The relationship between efficiency and competitive power of banking industry under Quiet Life Hypothesis is that higher the Market concentration, lower is the efficiency. But this study looks into competition and consecutive market concentration and the banks' efficiency. The Quiet Life Hypothesis insists on managerial efficiency tends to decline after the organisation attains the competitive pricing power. To measure the competition in the banking sector, Lerner Index is calculated for individual banks and aggregated into the mean value.
Indian commercial banks are known for resilience in any crisis because of its robust regulatory system imposed by RBI. Indian commercial banks are basically classified into Public sector banks, Private sector banks and Foreign banks. Public sector banks are known for attaining socio-economic objectives. Among public sector banks, SBI and its associates are dominating the banking space in terms of deposits, loans and scale of operations etc., The SBI's CEO Ms. Arundhati Bhattacharya, who was known for her sharp business acumen, emerged as a strong leader and brought SBI with changes in HR policies for women workforce, demonetisation aftermath, and made the mega merger of SBI and its associates. Whether her leadership had created a quiet life for successors to lean on? The quiet life hypothesis says the diminishing efficiency due to the management will relax and rest on market power and cash on pricing advantage.

\begin{tabular}{|c|c|c|c|c|c|c|c|c|}
\hline Bank & YEAR & 2018 & 2017 & 2016 & 2015 & 2014 & 2013 & MEAN \\
\hline \multirow{2}{*}{$\begin{array}{l}\text { STATE BANK OF } \\
\text { BIKANER \& JAIPUR }\end{array}$} & LI & ** & 0.205541 & 0.198588 & 0.20793 & 0.212066 & 0.186957 & 0.202216 \\
\hline & Cost Eff & ** & 0.025952 & 0.024501 & 0.036339 & 0.037788 & 0.031602 & 0.031236 \\
\hline \multirow{2}{*}{$\begin{array}{l}\text { STATE BANK OF } \\
\text { HYDERABAD }\end{array}$} & LI & $\star \star$ & 0.208143 & 0.214228 & 0.203589 & 0.202461 & 0.205193 & 0.206723 \\
\hline & Cost Eff & ** & 0.055469 & 0.058401 & 0.048566 & 0.048735 & 0.04675 & 0.051584 \\
\hline \multirow[b]{2}{*}{ STATE BANK OF INDIA } & LI & 0.213856 & 0.191278 & 0.204779 & 0.199015 & 0.203347 & 0.202409 & 0.202447 \\
\hline & Cost Eff & 1 & 1 & 0.65244 & 0.551567 & 0.479342 & 0.418861 & 0.683702 \\
\hline \multirow{2}{*}{$\begin{array}{l}\text { STATE BANK OF } \\
\text { MYSORE }\end{array}$} & LI & & 0.154605 & 0.159754 & 0.166705 & 0.167754 & 0.174766 & 0.164717 \\
\hline & Cost Eff & & 0.026345 & 0.028983 & 0.029916 & 0.027797 & 0.028617 & 0.028332 \\
\hline \multirow{2}{*}{$\begin{array}{l}\text { STATE BANK OF } \\
\text { PATIALA }\end{array}$} & LI & & 0.192739 & 0.200529 & 0.198691 & 0.199667 & 0.2084 & 0.200005 \\
\hline & Cost Eff & & 0.033849 & 0.048359 & 0.037496 & 0.035391 & 0.039146 & 0.038848 \\
\hline \multirow{2}{*}{$\begin{array}{l}\text { STATE BANK OF } \\
\text { TRAVANCORE }\end{array}$} & LI & & 0.197976 & 0.211168 & 0.197508 & 0.201152 & 0.213341 & 0.204229 \\
\hline & Cost Eff & & 0.03145 & 0.04161 & 0.034068 & 0.033593 & 0.03863 & 0.03587 \\
\hline
\end{tabular}

The obtained LI and DEA of SBI \& its associated is presented in (Table 1).

Table 1. Yearly \& Mean computation of LI and CE before and after the exit of Ms. Bhattacharya 
The obtained LI and DEA of Public Sector Banks is presented in (Table 2).

Table 2. LI and CE- Public Sector Banks

\begin{tabular}{|c|c|c|c|c|c|c|c|c|}
\hline Bank & YEAR & 2018 & 2017 & 2016 & 2015 & 2014 & 2013 & MEAN \\
\hline \multirow{2}{*}{ ALLAHABAD BANK } & LI & 0.221918 & 0.203188 & 0.202165 & 0.209422 & 0.203497 & 0.200338 & 0.206755 \\
\hline & Cost Eff & 0.080818 & 0.085582 & 0.090064 & 0.077421 & 0.074386 & 0.070509 & 0.079797 \\
\hline \multirow{2}{*}{ ANDHRA BANK } & $\mathrm{LI}$ & 0.247086 & 0.211679 & 0.207495 & 0.201891 & 0.22202 & 0.221367 & 0.21859 \\
\hline & Cost Eff & 0.096084 & 0.078386 & 0.080173 & 0.070593 & 0.068521 & 0.057477 & 0.075206 \\
\hline \multirow{2}{*}{ BANK OF BARODA } & $\mathrm{LI}$ & 0.22352 & 0.242533 & 0.236705 & 0.247117 & 0.240496 & 0.230515 & 0.236814 \\
\hline & Cost Eff & 0.284824 & 0.265738 & 0.239701 & 0.287904 & 0.250492 & 0.223095 & 0.258626 \\
\hline \multirow{2}{*}{ BANK OF INDIA } & LI & 0.248684 & 0.232215 & 0.219053 & 0.201269 & 0.203031 & 0.212349 & 0.219433 \\
\hline & Cost Eff & 0.197288 & 0.213575 & 0.201998 & 0.229025 & 0.227989 & 0.186852 & 0.209454 \\
\hline \multirow{2}{*}{ BANK OF MAHARASHTRA } & LI & 0.209044 & 0.19761 & 0.194139 & 0.186764 & 0.179815 & 0.180178 & 0.191258 \\
\hline & Cost Eff & 0.047736 & 0.043338 & 0.056552 & 0.048821 & 0.047565 & 0.046707 & 0.048453 \\
\hline \multirow{2}{*}{ CANARA BANK } & $\mathrm{LI}$ & 0.221224 & 0.196441 & 0.182343 & 0.170791 & 0.172258 & 0.185921 & 0.188163 \\
\hline & Cost Eff & 0.201588 & 0.235141 & 0.231405 & 0.283597 & 0.26785 & 0.170937 & 0.231753 \\
\hline \multirow{2}{*}{ CENTRAL BANK OF INDIA } & $\mathrm{LI}$ & 0.220603 & 0.195863 & 0.177855 & 0.183691 & 0.186728 & 0.183626 & 0.191394 \\
\hline & Cost Eff & 0.09481 & 0.101118 & 0.111613 & 0.098237 & 0.085135 & 0.09805 & 0.098161 \\
\hline \multirow{2}{*}{ CORPORATION BANK } & $\mathrm{LI}$ & 0.238978 & 0.221546 & 0.219217 & 0.227412 & 0.228878 & 0.23224 & 0.228045 \\
\hline & Cost Eff & 0.100638 & 0.140278 & 0.131026 & 0.145697 & 0.132508 & 0.119889 & 0.128339 \\
\hline \multirow{2}{*}{ DENA BANK } & $\mathrm{LI}$ & 0.180544 & 0.181522 & 0.18611 & 0.195075 & 0.19688 & 0.201682 & 0.190302 \\
\hline & Cost Eff & 0.032675 & 0.042053 & 0.041695 & 0.051694 & 0.050552 & 0.053559 & 0.045371 \\
\hline \multirow{2}{*}{ IDBI BANK LIMITED } & $\mathrm{LI}$ & 0.220147 & 0.199685 & 0.205749 & 0.202386 & 0.211752 & 0.209313 & 0.208172 \\
\hline & Cost Eff & 0.214013 & 0.18918 & 0.254475 & 0.215406 & 0.236321 & 0.214963 & 0.220726 \\
\hline \multirow{2}{*}{ INDIAN BANK } & $\mathrm{LI}$ & 0.204572 & 0.191015 & 0.181695 & 0.186085 & 0.178104 & 0.178882 & 0.186725 \\
\hline & Cost Eff & 0.096844 & 0.101239 & 0.110025 & 0.101701 & 0.102198 & 0.058166 & 0.095029 \\
\hline \multirow{2}{*}{ INDIAN OVERSEAS BANK } & $\mathrm{LI}$ & 0.233533 & 0.205541 & 0.186479 & 0.192888 & 0.193957 & 0.196971 & 0.201561 \\
\hline & Cost Eff & 0.077092 & 0.069825 & 0.085755 & 0.101843 & 0.106467 & 0.089286 & 0.088378 \\
\hline \multirow{2}{*}{$\begin{array}{l}\text { ORIENTAL BANK OF } \\
\text { COMMERCE }\end{array}$} & $\mathrm{LI}$ & 0.228435 & 0.21376 & 0.200303 & 0.211901 & 0.209526 & 0.205569 & 0.211582 \\
\hline & Cost Eff & 0.097118 & 0.092527 & 0.093778 & 0.112619 & 0.09978 & 0.089307 & 0.097522 \\
\hline \multirow{2}{*}{ PUNJAB AND SIND BANK } & LI & 0.187051 & 0.173592 & 0.187608 & 0.190608 & 0.188229 & 0.186277 & 0.185561 \\
\hline & Cost Eff & 0.031303 & 0.037937 & 0.046114 & 0.04505 & 0.04623 & 0.037134 & 0.040628 \\
\hline \multirow{2}{*}{ PUNJAB NATIONAL BANK } & $\mathrm{LI}$ & 0.220862 & 0.232811 & 0.22849 & 0.230255 & 0.223755 & 0.203008 & 0.223197 \\
\hline & Cost Eff & 0.176301 & 0.27068 & 0.201009 & 0.167511 & 0.149948 & 0.140982 & 0.184405 \\
\hline \multirow{2}{*}{ SYNDICATE BANK } & LI & 0.236147 & 0.209814 & 0.214862 & 0.212788 & 0.209567 & 0.19972 & 0.213816 \\
\hline & Cost Eff & 0.085485 & 0.082063 & 0.102764 & 0.116863 & 0.081658 & 0.066598 & 0.089238 \\
\hline \multirow{2}{*}{ UCO BANK } & $\mathrm{LI}$ & 0.210984 & 0.206656 & 0.21112 & 0.224919 & 0.226373 & 0.217891 & 0.216324 \\
\hline & Cost Eff & 0.064344 & 0.079637 & 0.097435 & 0.115928 & 0.10944 & 0.091445 & 0.093038 \\
\hline \multirow{2}{*}{ UNION BANK OF INDIA } & $\mathrm{LI}$ & 0.232873 & 0.210355 & 0.1938 & 0.192618 & 0.193137 & 0.199987 & 0.203795 \\
\hline & Cost Eff & 0.204701 & 0.179677 & 0.15127 & 0.130038 & 0.124651 & 0.113596 & 0.150656 \\
\hline \multirow{2}{*}{ UNITED BANK OF INDIA } & $\mathrm{LI}$ & 0.199677 & 0.188816 & 0.167448 & 0.206509 & 0.211823 & 0.203075 & 0.196225 \\
\hline & Cost Eff & 0.03685 & 0.039526 & 0.036846 & 0.051199 & 0.052751 & 0.045943 & 0.043853 \\
\hline \multirow{2}{*}{ VIJAYA BANK } & $\mathrm{LI}$ & 0.212786 & 0.191354 & 0.195759 & 0.209395 & 0.212633 & 0.210545 & 0.205412 \\
\hline & Cost Eff & 0.056812 & 0.047797 & 0.058277 & 0.058292 & 0.054634 & 0.045763 & 0.053596 \\
\hline
\end{tabular}




\section{Overview of Public sector banks and their competition}

Though the Public sector banks in India enjoy the Government's patronage in terms of liquidity, infusion of capital during the NPA crisis, they never reached the advantage of competitive edge. The (Table 2), demonstrates clearly that no public sector bank had achieved highly competitive edge over the others.

\section{Lerner Index and Cost Efficiency of SBI \& Associates before and after the exit of Ms. Bhattacharya}

As the original QLH focuses on pricing edge through Lerner Index, this study focuses on Lerner index. The following table depicts the year wise SBI, associates of SBI and other public sector banks and their market power. Interestingly the pricing edge is not enjoyed by SBI and its associates. The Lerner Index of SBI and its associates hardly range from 0.15 to 0.21 . It is proven that, given the autonomy to all banks, the government owned banks did not move much beyond the RBI's directive lending rates over the various segments of loans. Ms. Bhattacharya's merger of all SBI and associates materialised in 2017 with Government's nod and SBI's Lerner Index in 2018 was 0.214.

\subsection{Modeling the Effect of Competition on the Efficiency}

To obtain the effect of competition obtained by Lerner's Index on the efficiency of the banks is modelled by a simple regression as

$$
\mathrm{CE}=\alpha_{0}+\alpha_{1} \mathrm{LI}+\varepsilon .
$$

The result of regression analysis, the effect of LI and Efficiency of the considered public sector banks is presented in (figure 1).

The obtained regression equation is

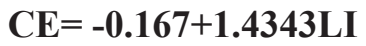

\section{Results and Findings}

It is observed that 'there is no absolute market power enjoyed by SBI till 2017 and after the exit of Ms Arundhati also, there is a slight increase in market

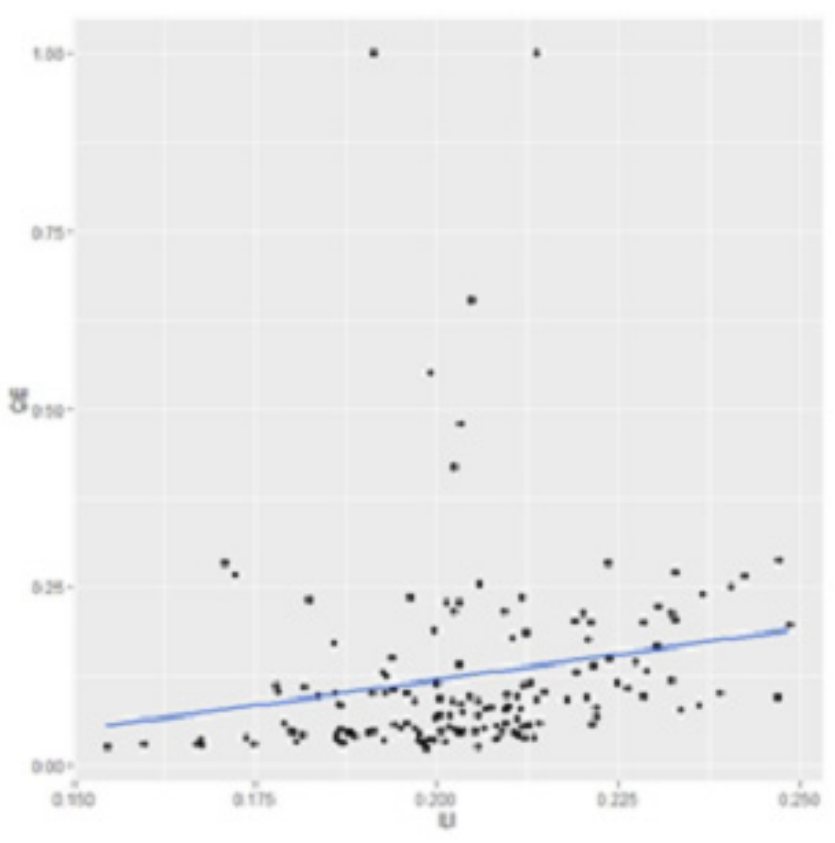

Figure 1. The effect of LI and efficiencies of Public sector Banks.

power of SBI after the mergers. The concept of Market power was not enjoyed by SBI and its associates before and after tenure by Ms Arundhati. The LI of 0.9 indexes says the absolute market power. Hence the QLH is preceded with only efficiency parameter to say whether QLH really enjoyed by successors and led to inefficiency or not. Even other public sector banks also did not have market power so far. Because all of them had only 0.15 to 0.20

The highest efficiency score of 1 was achieved by SBI in 2017. The same efficiency level continued 1 in 2018. The legacy of SBI continued with the huge merger of Indian banking history led to the highest efficiency of 1 in 2018.

Compared to other public sector banks, only SBI achieved the highest efficiency score and other public sector banks are far behind in terms of cost efficiency. The cost advantage is clearly achieved by the leadership by the $\mathrm{CEO}$ and it continues.

\section{Conclusion}

The following are the significant outcomes of the study and conclusion of the study: 
1. The preposition of QLH started with the efficiency of SBI will decrease after the exit of its CEO, but it has been proved that QLH did not lead to lower efficiency and it is not true based on the F-test and p-value.

2. Moreover, it is also noticed that there is no competition among the public sector banks and no banks' Lerner's index exceeded .024.

3. It is observed that Lerner's index does not influence the efficiency of Public sector Banks.

4. Importantly, QLH has proved wrong and that may be the Quiet Life period is one year which is considered for the study. The further studies on QLH could be conducted covering three years after her exit and may bring interesting outcomes. Moreover, the QLH can be applied to the institutions which experienced phenomenal growth under the extraordinary leadership and their exit and aftermath. The research could also be explored in different styles of leadership and their impact on the institutional performances using qualitative parameters beyond the cost, profit and market leadership.

\section{References}

Asongu, S. A., Odhiambo, N. M. 2019. Testing the quiet life hypothesis in the African banking industry. Journal of Industry, Competition and Trade, 19. 69-82. https://doi. org/10.1007/s10842-018-0278-3
Banker, R.D., Charnes, A., and Cooper, W.W. (1984). "Some models for estimating technical and scale inefficiencies in data envelopment analysis". Management Science. 30(9): 1078-1092.

Charnes, A., Cooper, W.W., and Rhodes, E., (1978). "Measuring the efficiency of decision making units". European Journal of Operational Research. 2(6): 429-444.

Inoue, K. (2018). The "Quiet Life Hypothesis" is real: Mangers will put off Hard Decisions if they can. Havard Business Review, Jan 09, 2018. https://hbr.org/2018/01/ the-quiet-life-hypothesis-is-real-managers-will-put-offhard-decisions-if-they-can

Liem, M. C. (2019). Quiet Life Hypothesis reborn: is holidinglisation relevant? Managerial Finance, 45(2), 278-93. https://doi.org/10.1108/MF-08-2017-0279

Mehta, M. N. (2010). Financial reporting quality \& the quiet life. Sloan School of Management. https://doi.org/10.2139/ssrn.1535704

Odhiambo, S. A. (2019). Testing the quiet life hypothesis in the african banking industry. Journal of Industry, Competition and Trade, 19(1), 20. https://doi.org/10.2139/ ssrn. 3175048

Rolf Fare, S. Shawna Grosskopf, Joaquín Maudos. (2015). Revisiting the quiet life hypothesis in banking using nonparametric techniques. Journal of Business Economics and Management. https://doi.org/10.3846/16111699.201 2.726929

Venkatesh, K. A., Narasimhan, P. (2019). Performance evaluation and measures. In G R Sinha (Editor), Modern Optimization Methods for Science, Engineering and Technology. https://doi.org/10.1088/978-0-7503-2404$5 \operatorname{ch} 10$ 


\section{Appendix}

\begin{tabular}{|c|c|c|c|c|c|}
\hline \multicolumn{4}{|c|}{ Translog function coefficients and Result } & & \\
\hline \multicolumn{6}{|c|}{ Residuals: } \\
\hline Min & $1 Q$ & Median & $3 Q$ & $\operatorname{Max}$ & \\
\hline-0.145233 & -0.022652 & 0.003614 & 0.029090 & 0.108410 & \\
\hline \multicolumn{6}{|c|}{ Coefficients: } \\
\hline & & Estimate & Std. Error & t value & $\operatorname{Pr}(>|t|)$ \\
\hline (Intercept) & & -2.751954 & $4.027344-$ & 0.683 & 0.4955 \\
\hline $\log (\mathrm{CPC})$ & & 0.604242 & 0.329820 & 1.832 & 0.0691. \\
\hline $\log (\mathrm{COF})$ & - & 0.519635 & 0.905219 & -0.574 & 0.5669 \\
\hline $\log (\mathrm{LC})$ & & -0.500125 & 0.695149 & -0.719 & 0.4731 \\
\hline $\log (T A)$ & & 0.863600 & 0.355529 & 2.429 & 0.0164 * \\
\hline \multicolumn{2}{|c|}{$\mathrm{I}\left(0.5^{*} \log (\mathrm{TA})^{\wedge} 2\right)$} & 0.013047 & 0.015303 & 0.853 & 0.3954 \\
\hline \multicolumn{2}{|c|}{$\mathrm{I}\left(\log (\mathrm{CPC}){ }^{*} \log (\mathrm{COF})\right)$} & -0.062341 & 0.086741 & -0.719 & 0.4735 \\
\hline \multicolumn{2}{|c|}{$I(\log (T A) * \log (C P C))$} & -0.021826 & 0.013975 & -1.562 & 0.1206 \\
\hline \multicolumn{2}{|c|}{$\mathrm{I}\left(\log (\mathrm{TA}){ }^{*} \log (\mathrm{COF})\right)$} & 0.073039 & 0.065309 & 1.118 & 0.2653 \\
\hline \multicolumn{2}{|c|}{$I\left(\log (T A) *{ }^{*} \log (L C)\right)$} & 0.037066 & 0.033307 & 1.113 & 0.2677 \\
\hline \multicolumn{2}{|c|}{$\mathrm{I}\left(\log (\mathrm{CPC}) *{ }^{*} \log (\mathrm{LC})\right)$} & 0.028688 & 0.031259 & 0.918 & 0.3603 \\
\hline \multicolumn{2}{|c|}{$\mathrm{I}(\log (\mathrm{COF}) * \log (\mathrm{LC}))-0.005009$} & 0.164361 & -0.030 & 0.9757 & \\
\hline
\end{tabular}

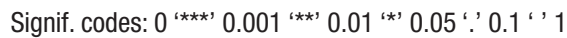

Residual standard error: 0.04428 on 139 degrees of freedom

Multiple R-squared: 0.9964, Adjusted R-squared: 0.9961

F-statistic: 3459 on 11 and $139 \mathrm{DF}, \mathrm{p}$-value: $<2.2 \mathrm{e}-16$

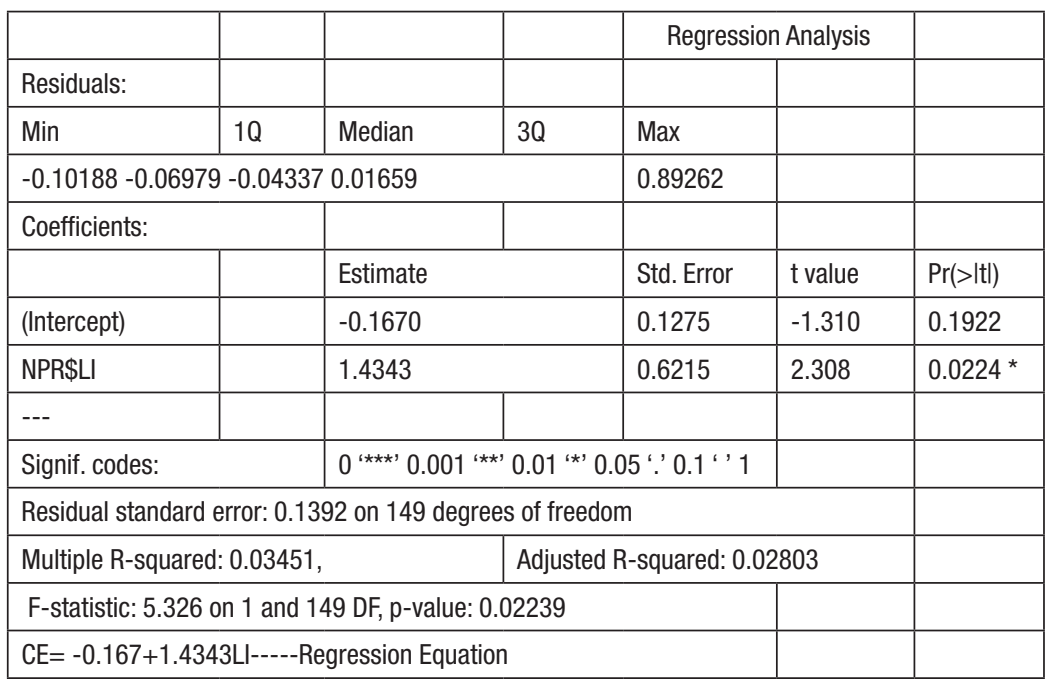

Analysis of Variance Table

Response: NPR\$CE

Response: NPR\$CE

Sum Sq Mean Sq F value $\operatorname{Pr}(>\mathrm{F})$

NPR\$LI 10.103160 .103165 .32580 .02239 *

Residuals 1492.886100 .01937

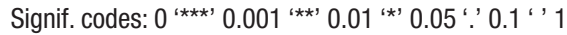

